\title{
Przetwarzanie danych osobowych do celów badań naukowych. Aspekty prawne
}

\section{Wprowadzenie}

Rozporządzenie Parlamentu Europejskiego i Rady (UE) 2016/679 z 27 kwietnia 2016 r. w sprawie ochrony osób fizycznych w związku z przetwarzaniem danych osobowych i w sprawie swobodnego przepływu takich danych ${ }^{1}$ jest stosowane od dnia 25 maja 2018 r. i odnosi się również do procesów przetwarzania danych osobowych do celów badań naukowych. Powołany akt normatywny określa m.in. prawne podstawy dopuszczalności przetwarzania danych osobowych, ogólne zasady dotyczące ich przetwarzania, obowiązki spoczywające na administratorach, a także prawa osób, których dane dotyczą. W pełni zatem znajduje zastosowanie do procesów przetwarzania danych do celów badań naukowych. Zgodnie z motywem 159 preambuły ogólnego rozporządzenia, „jeżeli dane osobowe są przetwarzane do celów badań naukowych, niniejsze rozporządzenie powinno mieć zastosowanie także do takiego przetwarzania. W niniejszym rozporządzeniu przetwarzanie danych osobowych do celów badań naukowych należy interpretować szeroko, obejmując tym pojęciem na przykład rozwój technologiczny i demonstrację, badania podstawowe, badania stosowane oraz badania finansowane ze środków prywatnych. Ponadto należy uwzględnić cel Unii określony w art. 179 ust. 1 TFUE, którym jest utworzenie europejskiej przestrzeni badawczej. Wyrażenie «do celów badań naukowych» powinno obejmować także badania prowadzone $\mathrm{w}$ interesie publicznym $\mathrm{w}$ dziedzinie zdrowia publicznego. Z uwagi na specyfikę przetwarzania danych osobowych do

\footnotetext{
${ }^{1}$ Dz.Urz. UE L 119 z dnia 3 V 2016 r. ze zm., s. 1, dalej „ogólne rozporządzenie”.
} 
celów badań naukowych zastosowanie powinny mieć specjalne warunki, w szczególności w odniesieniu do publikacji lub innego ujawniania danych osobowych w kontekście celów badań naukowych. Jeżeli wynik badań naukowych, w szczególności w kontekście zdrowotnym, uzasadnia dalsze środki w interesie osoby, której dane dotyczą, do środków tych powinny mieć zastosowanie przepisy ogólne niniejszego rozporządzenia". Ogólne rozporządzenie nie definiuje jednak terminu "badania naukowe”. Jak wskazano w treści wytycznych Grupy Roboczej Art. 29 dotyczących zgody na mocy rozporządzenia 2016/679 przyjętych dnia 28 listopada 2017 r. ${ }^{2}$ (ostatnio zmienionych i przyjętych dnia 10 kwietnia 2018 r.), "GR29 uważa jednak, że pojęcia tego [badań naukowych - dop. A.P.] nie można rozciągać poza jego powszechne znaczenie, i jest zdania, że w tym kontekście [motywu 159 preambuły ogólnego rozporządzenia dop. A.P.] «badania naukowe» oznaczają projekt badawczy zorganizowany zgodnie $\mathrm{z}$ odpowiednimi normami metodycznymi i etycznymi $\mathrm{w}$ danym sektorze oraz zgodnie z dobrymi praktykami"3. Biorąc pod uwagę, że zagadnienie przetwarzania danych osobowych do celów badań naukowych prezentowane było $\mathrm{w}$ piśmiennictwie stosunkowo rzadko, zasadne jest podjęcie rozważań w szerszym aspekcie, niż miało to miejsce dotychczas. Z tego względu celem niniejszego opracowania jest przedstawienie zagadnienia przetwarzania danych osobowych do celów badań naukowych w świetle rozporządzenia Parlamentu Europejskiego i Rady (UE) 2016/679 z dnia 27 kwietnia 2016 r. w sprawie ochrony osób fizycznych w związku z przetwarzaniem danych osobowych i w sprawie swobodnego przepływu takich danych oraz uchylenia dyrektywy 95/46/WE. Najistotniejsze jest omówienie zagadnienia realizacji praw osób, których dane dotyczą; podstaw dopuszczalności przetwarzania danych; anonimizacji danych po osiągnięciu celu przetwarzania, udostępniania danych dotyczących wyroków skazujących i czynów zabronionych z rejestrów publicznych, a także nawiązanie do zagadnienia przetwarzania danych osobowych do celów badań naukowych przez biobanki.

2 17/PL, WP259 rev. 01, https://uodo.gov.pl/pl/10/428 (dostęp: 9 XII 2019).

${ }^{3}$ Zgodnie z art. 4 ust. 2 Ustawy z dnia 20 VII 2018 r. Prawo o szkolnictwie wyższym i nauce (Dz.U. 2018, poz. 1668) „badania naukowe są działalnością obejmującą: 1) badania podstawowe rozumiane jako prace empiryczne lub teoretyczne mające przede wszystkim na celu zdobywanie nowej wiedzy o podstawach zjawisk i obserwowalnych faktów bez nastawienia na bezpośrednie zastosowanie komercyjne; 2) badania aplikacyjne rozumiane jako prace mające na celu zdobycie nowej wiedzy oraz umiejętności, nastawione na opracowywanie nowych produktów, procesów lub usług lub wprowadzanie do nich znaczących ulepszeń". 
Do problematyki przetwarzania danych osobowych do celów badań naukowych nawiązywała również rekomendacja Rady Europy R(83) 10 z dnia 23 września 1983 r. dotycząca ochrony danych osobowych wykorzystywanych $\mathrm{w}$ badaniach naukowych i statystyce ${ }^{4}$. Powołana rekomendacja znajdowała zastosowanie zarówno do podmiotów z sektora publicznego, jak i prywatnego, nie ograniczając jednocześnie swego zastosowania do procesów przetwarzania danych osobowych prowadzonych wyłącznie w sposób automatyczny ${ }^{5}$. W treści załącznika do powyższej rekomendacji Rady Europy zawarto postanowienia odnoszące się do zgody udzielanej przez osobę, której dane dotyczą; posługiwania się danymi na potrzeby badań naukowych; tworzenia próbek; dostępu do danych osób, których one dotyczą; bezpieczeństwa danych; upubliczniania danych; przechowywania danych, a także tworzenia komisji w ramach wspólnoty naukowców. Materia ta została jednak uregulowana w niewyczerpujący sposób, co pozostawiało administratorom swobodę m.in. w zakresie doboru środków technicznych i organizacyjnych zapewniających bezpieczeństwo i poufność danych. Warto nadmienić, że do takiego rozwiązania powrócił prawodawca unijny w ogólnym rozporządzeniu.

\section{Prawne podstawy dopuszczalności przetwarzania danych osobowych do celów badań naukowych}

\subsection{Podstawy dopuszczalności przetwarzania tzw. "danych zwykłych" i danych dotyczących wyroków skazujących i czynów zabronionych}

Prawodawca uregulował w ogólnym rozporządzeniu zarówno podstawy dopuszczalności przetwarzania tzw. „danych zwykłych” (art. 6 ust. 1 ogólnego rozporządzenia), jak i szczególnych kategorii danych osobowych (art. 9 ust. 2 ogólnego rozporządzenia)6. Przetwarzanie

\footnotetext{
${ }^{4}$ https://uodo.gov.pl/pl/131/524 (dostęp: 14 XII 2019).

${ }^{5}$ W przeciwieństwie do przepisów Konwencji Nr 108 Rady Europy sporządzonej w Strasburgu dnia 28 stycznia 1981 r. o ochronie osób w związku z automatycznym przetwarzaniem danych osobowych (Dz.U. 2003 Nr 3, poz. 25) znajdujących zasadniczo zastosowanie do procesów przetwarzania prowadzonych w sposób automatyczny.

${ }^{6}$ Do danych osobowych szczególnych kategorii należy zaliczyć dane osobowe ujawniające pochodzenie rasowe lub etniczne, poglądy polityczne, przekonania religijne lub światopoglądowe, przynależność do związków zawodowych, dane genetyczne, dane
} 
danych osobowych do celów badań naukowych może wiązać się zarówno z przetwarzaniem "danych zwykłych", danych szczególnych kategorii, jak i danych osobowych dotyczących wyroków skazujących i czynów zabronionych (art. 10 ogólnego rozporządzenia). Ogólne rozporządzenie nie zawiera odrębnych przepisów w zakresie przesłanek legalizujących przetwarzanie danych w postaci wyroków skazujących i czynów zabronionych, a więc znajdzie tu zastosowanie przepis art. 6 ust. 1 ogólnego rozporządzenia. Tym samym podejmując rozważania dotyczące możliwości zastosowania określonych przesłanek legalizujących przetwarzanie danych, należy brać pod uwagę zarówno przepis art. 6 ust. 1, jak i art. 9 ust. 2 ogólnego rozporządzenia.

W myśl tego rozporządzenia jedną z podstaw dopuszczalności przetwarzania danych zwykłych jest zgoda osoby, której dane dotyczą art. 6 ust. 1 lit. a. Jak stanowi ten przepis, przetwarzanie jest zgodne z prawem, gdy - i w takim zakresie, w jakim - osoba, której dane dotycza, wyraziła zgodę na przetwarzanie swoich danych osobowych w jednym lub większej liczbie określonych celów. Zgodę na przetwarzanie danych osobowych do celów badań naukowych należy w pełni oddzielić od zgody na udział w badaniu naukowym. Zgoda jest w zupełności autonomiczną przesłanką legalizującą przetwarzanie danych osobowych, co oznacza, że w pełni dopuszcza się przetwarzanie danych osobowych wyłącznie na jej podstawie, a więc bez konieczności wykazywania zaistnienia innych przesłanek ${ }^{7}$. Niemniej warto nadmienić, że zgoda jest dobrowolnym, konkretnym, świadomym i jednoznacznym okazaniem woli, którym osoba, której dane dotyczą, w formie oświadczenia lub

biometryczne (przetwarzane w celu jednoznacznego zidentyfikowania osoby fizycznej), dane dotyczące zdrowia, seksualności lub orientacji seksualnej - art. 9 ust. 1 ogólnego rozporządzenia.

${ }^{7}$ Szerzej na temat zgody na przetwarzanie danych osobowych zob. Article 29 Data Protection Working Party, Guidelines on consent under Regulation 2016/679, wersja elektroniczna, https://ec.europa.eu/newsroom/article29/item-detail.cfm?item_id=623051 (dostęp: 31 X 2019); A. Mednis, Cechy zgody na przetwarzanie danych osobowych w opinii Grupy Roboczej Art. 29 dyrektywy 95/46 Nr 15/2011 (WP 187), "Monitor Prawniczy” 2012, nr 7, dodatek; P. Fajgielski, Zgoda na przetwarzanie danych osobowych w przepisach ogólnego rozporzadzenia o ochronie danych, „Informacja w Administracji Publicznej” 2016, nr 4; idem, Ogólne rozporządzenie o ochronie danych. Ustawa o ochronie danych osobowych. Komentarz, Warszawa 2018, s. 162-166; B. Matasek, Treść klauzuli zgody na gruncie RODO, "Informacja w Administracji Publicznej" 2018, nr 2; U. Winkowska-Zakrzewska, Zgoda na przetwarzanie danych osobowych, "Informacja w Administracji Publicznej” 2015, nr 2; J. Byrski, Odwołanie zgody na przetwarzanie danych osobowych. Wybrane zagadnienia, "Monitor Prawniczy" 2011, nr 3, dodatek. 
wyraźnego działania potwierdzającego, przyzwala na przetwarzanie dotyczących jej danych osobowych (art. 4 pkt 11 ogólnego rozporządzenia). Zgodnie z art. 5 ust. 2 ogólnego rozporządzenia administrator jest odpowiedzialny za przestrzeganie przepisów dotyczących zasad przetwarzania danych osobowych i musi być w stanie wykazać ich przestrzeganie, a tym samym to na tym podmiocie ciąży obowiązek doboru właściwej podstawy dopuszczalności przetwarzania danych w kontekście stosowania m.in. zasady zgodności z prawem, rzetelności i przejrzystości - art. 5 ust. 1 lit. a ogólnego rozporządzenia. Należy jednak zwrócić uwagę, że prawodawca unijny nawiązuje do zgody w motywie 33 preambuły ogólnego rozporządzenia, zgodnie z którym "W momencie zbierania danych często nie da się w pełni zidentyfikować celu przetwarzania danych osobowych na potrzeby badań naukowych. Dlatego osoby, których dane dotycza, powinny móc wyrazić zgodę na niektóre obszary badań naukowych, o ile badania te są zgodne z uznanymi normami etycznymi w zakresie badań naukowych. Osoby, których dane dotyczą powinny móc wyrazić zgodę tylko na niektóre obszary badań lub elementy projektów badawczych, o ile umożliwia to zamierzony cel". Do kwestii odbierania zgód na przetwarzanie danych osobowych do celów badań naukowych odniosła się również Komisja Europejska ${ }^{8}$.

Zgoda na przetwarzanie tzw. "danych zwykłych" i danych dotyczących wyroków skazujących i czynów zabronionych jest niewyłączną przesłanka, gdyż wyróżnić należy także inne podstawy dopuszczalności przetwarzania danych, a więc te, które zostały zawarte w art. 6 ust. 1 lit. b-f ogólnego rozporządzenia9. Prawodawca wskazał, że przetwarzanie jest zgodne $\mathrm{z}$ prawem wyłącznie $\mathrm{w}$ przypadkach, gdy - i w takim zakresie, w jakim - przetwarzanie jest niezbędne do wykonania umowy, której stroną jest osoba, której dane dotycza, lub do podjęcia działań na żądanie osoby, której dane dotyczą, przed zawarciem umowy (lit. b); przetwarzanie jest niezbędne do wypełnienia obowiązku prawnego ciążącego na administratorze (lit. c) ${ }^{10}$; przetwarzanie jest

${ }^{8}$ Szerzej zob. https://ec.europa.eu/info/law/law-topic/data-protection/reform/ rules-business-and-organisations/legal-grounds-processing-data/grounds-processing/ how-consent-processing-scientific-research-obtained_pl (dostęp: 31 X 2019).

${ }^{9}$ Szerzej na temat innych przesłanek legalizujących przetwarzanie danych osobowych zob. Rozporzadzenie UE w sprawie ochrony osób fizycznych w związu z przetwarzaniem danych osobowych i swobodnym przeptywem takich danych. Komentarz, pod red. P. Litwińskiego, P. Barty, M. Kaweckiego, Warszawa 2018, s. 293-312.

${ }^{10}$ Warto nadmienić, że zgodnie z art. 6 ust. 3 ogólnego rozporządzenia „podstawa przetwarzania, o którym mowa w ust. 1 lit. c) i e), musi być określona: a) w prawie Unii; 
niezbędne do ochrony żywotnych interesów osoby, której dane dotycza, lub innej osoby fizycznej (lit. d); przetwarzanie jest niezbędne do wykonania zadania realizowanego $w$ interesie publicznym lub $w$ ramach sprawowania władzy publicznej powierzonej administratorowi (lit. e); a także gdy przetwarzanie jest niezbędne do celów wynikających z prawnie uzasadnionych interesów realizowanych przez administratora lub przez stronę trzecią, $\mathrm{z}$ wyjątkiem sytuacji, w których nadrzędny charakter wobec tych interesów mają interesy lub podstawowe prawa i wolności osoby, której dane dotycza, wymagające ochrony danych osobowych, w szczególności gdy osoba, której dane dotycza, jest dzieckiem (lit. f). W piśmiennictwie prezentowany jest pogląd, że spośród wskazanych powyżej przesłanek legalizujących przetwarzanie danych osobowych, do przetwarzania danych w celu badań naukowych może znaleźć również zastosowanie podstawa z art. 6 ust. 1 lit. f ogólnego rozporządzenia, $\mathrm{tj}$. wynikająca $\mathrm{z}$ zaistnienia prawnie uzasadnionego interesu administratora (ang. legitimate interest) ${ }^{11}$. Odnosząc się do tego stanowiska, należy nadmienić, że administratorami w procesach przetwarzania danych osobowych do celów badań naukowych są zarówno podmioty prywatne, jak i podmioty publiczne, co nie pozostaje bez znaczenia w kwestii powoływania się na podstawę z art. 6 ust. 1 lit. f ogólnego rozporządzenia. Jak wynika z końcowej części przepisu art. 6 ust. 1 ogólnego rozporządzenia, „akapit pierwszy lit. f) nie ma zastosowania do przetwarzania, którego dokonują organy publiczne w ramach realizacji swoich zadań". Oznacza to, że "omawiana tu przesłanka może być stosowana jedynie przez podmioty prywatne (np. przedsiębiorców), natomiast nie mogą się na nią powoływać podmioty publiczne"12. Ponadto należy zwrócić uwagę, że administrator może powołać się na istnienie prawnie uzasadnionego interesu, o ile nie mają nadrzędnego charakteru interesy lub podstawowe prawa i wolności osób, których dane dotycza, wymagające jednocześnie ochrony danych osobowych. Powoływanie się na omawianą przesłankę powinno być zatem poprzedzone przeprowadzeniem analizy

lub b) w prawie państwa członkowskiego, któremu podlega administrator". Szerzej na ten temat zob. M. Gumularz, Ochrona danych osobowych w sektorze publicznym, Warszawa 2018, s. 116-117.

${ }^{11}$ Szerzej zob. Z. Warso, Przetwarzanie danych osobowych do celów badań naukowych w świetle ogólnego rozporządzenia o ochronie danych osobowych, w: Wybrane aspekty praw człowieka a bioetyka, pod red. A. Białek, M. Wróblewskiego, Warszawa 2016, s. 44-45.

12 Zob. P. Fajgielski, Ogólne rozporządzenie..., s. 176. 
nadrzędności interesów administratora i podmiotów danych (w tym praw osób, których dane dotyczą). Przyjęcie takiego stanowiska oznaczałoby jednocześnie, że prawnie uzasadniony interes administratora jest związany z osiągnięciem wyników badań naukowych. Niemniej należy jednocześnie dodać, iż nie sposób jednoznacznie zdefiniować pojęcia "uzasadniony interes", na co wskazywano w orzecznictwie sądów administracyjnych ${ }^{13}$ ( $w$ odniesieniu do równoważnego określenia "usprawiedliwiony cel” na gruncie nieobowiązującej ustawy z dnia 29 sierpnia 1997 r. o ochronie danych osobowych ${ }^{14}$ ). Przyjęcie za podstawę przesłanki z art. 6 ust. 1 lit. f ogólnego rozporządzenia wiązać się będzie dodatkowo z koniecznością realizacji prawa do sprzeciwu $\mathrm{z}$ art. 21 tego aktu.

\subsubsection{Udostępnienie danych zgromadzonych w Krajowym Rejestrze Karnym do celów badań naukowych}

Zgodnie z art. 8 ust. 1 Ustawy z dnia 24 maja 2000 r. o Krajowym Rejestrze Karnym ${ }^{15}$ "zgromadzone w zbiorach Rejestru dane osobowe moga być przetwarzane i wykorzystywane do badań naukowych, a także, po pozbawieniu tych danych informacji identyfikujących osobę, do celów statystycznych". Powołany przepis odnosi się do kwestii przetwarzania danych osobowych m.in. do celów badań naukowych, dla prowadzenia których nie jest niezbędne pozbawienie danych informacji umożliwiających identyfikację (do czasu osiągnięcia celu przetwarzania), co powinno mieć miejsce w przypadku przetwarzania danych do celów statystycznych. W takim przypadku nie należy posługiwać się już pojęciem danych osobowych, gdyż dane, które nie umożliwiają identyfikacji osoby fizycznej, nie są danymi osobowymi. Takiego obostrzenia nie wprowadzono w ustawie o Krajowym Rejestrze Karnym w przypadku przetwarzania danych osobowych do celów badań naukowych, stąd też dane pozyskiwane do tego celu będą umożliwiać identyfikację osób fizycznych do czasu poddania danych anonimizacji (tj. niezwłocznie po osiągnięciu celu badań naukowych zgodnie $\mathrm{z}$ art. $469 \mathrm{~b}$ ust. 4 ustawy

${ }^{13}$ Szerzej zob. wyrok Naczelnego Sądu Administracyjnego z 19 XI 2001 r., sygn. II SA 2702/00, niepubl.; zob. też Rozporządzenie UE..., s. 304-305.

${ }^{14}$ Ustawa z dnia 29 VIII 1997 r. o ochronie danych osobowych (tekst jedn. Dz.U. 2016, poz. 922).

15 Tekst jedn. Dz.U. 2019, poz. 1158. 
Prawo o szkolnictwie wyższym i nauce $\left.{ }^{16}\right)^{17}$. Jak stanowi art. 8 ust. 2 ustawy o Krajowym Rejestrze Karnym, „udostępnione dane osobowe można wykorzystywać wyłącznie zgodnie z przeznaczeniem, dla którego zostały udostępnione". Wprowadzenie w ustawodawstwie krajowym obostrzenia co do możliwości przetwarzania danych wyłącznie w zgodzie z przeznaczeniem ich udostępnienia $\mathrm{z}$ rejestru nie jest konieczne. W tym przypadku można bowiem odnieść się do zasady ograniczenia celu uregulowanej w art. 5 ust. 1 lit. b ogólnego rozporządzenia, zgodnie z treścią której „dane osobowe muszą być zbierane w konkretnych, wyraźnych i prawnie uzasadnionych celach i nieprzetwarzane dalej w sposób niezgodny z tymi celami". Warto jednocześnie zwrócić uwagę, że ogólne rozporządzenie określa przetwarzanie do celów badań naukowych będące "dalszym przetwarzaniem" (wtórnym) jako zgodne z pierwotnym celem.

Prawodawca wskazał również podstawy do udzielenia przez administratora danych odmowy w udostępnieniu danych osobowych z Krajowego Rejestru Karnego, do których zaliczyć należy: ujawnienie wiadomości zawierających informacje niejawne; zagrożenie dla obronności lub bezpieczeństwa państwa, życia i zdrowia ludzi lub bezpieczeństwa i porządku publicznego; zagrożenie dla podstawowego interesu gospodarczego lub finansowego państwa; a także istotne naruszenie dóbr osobistych osób, których dane dotycza, lub innych osób (art. 8 ust. 3 ustawy o Krajowym Rejestrze Karnym). Szczegółowe kwestie związane z udostępnianiem danych osobowych z Krajowego Rejestru Karnego reguluje Rozporządzenie Ministra Sprawiedliwości z dnia 1 lipca 2015 r. w sprawie szczegółowych zasad i sposobu przetwarzania oraz przekazywania danych osobowych zgromadzonych w zbiorach Krajowego Rejestru Karnego do celów statystycznych oraz badań naukowych ${ }^{18}$. Zgodnie z tym aktem „dane mogą być udostępniane do badań naukowych osobom fizycznym i jednostkom wyłącznie za zgodą Ministra Sprawiedliwości. Dane udostępnia się na pisemny i umotywowany wniosek. W uzasadnionych przypadkach udostępnia

${ }^{16}$ Ustawa z dnia 20 VII 2018 r. Prawo o szkolnictwie wyższym i nauce (Dz.U. poz. 1668).

${ }^{17}$ Szerzej na temat zasady ograniczenia przechowywania uregulowanej w art. 5 ust. 1 lit. e ogólnego rozporządzenia zob. M. Bienias, Zasada czasowego ograniczenia przechowywania danych osobowych na gruncie RODO, „Informacja w Administracji Publicznej" 2017, nr 4.

${ }^{18}$ Dz.U. 2015, poz. 984. 
się dane pozbawione informacji identyfikujących osobę" ( $\$ 3$ ust. 1). Jest to szczególna podstawa udostępnienia danych osobowych dotyczących wyroków skazujących i czynów zabronionych, a w myśl przepisów ogólnego rozporządzenia udostępnienie danych w tym przypadku stanowić będzie wypełnienie obowiązku prawnego ciążącego na administratorze - art. 6 ust. 1 lit. c ogólnego rozporządzenia (mimo że przepis $\S 3$ ust. 1 rozporządzenia w sprawie szczegółowych zasad i sposobu przetwarzania oraz przekazywania danych osobowych zgromadzonych w zbiorach Krajowego Rejestru Karnego do celów statystycznych oraz badań naukowych posługuje się zwrotem "mogą być"). Odmowa udostępnienia danych osobowych z Krajowego Rejestru Karnego do celów badań naukowych powinna być uzasadniona, stąd też nieprzekazanie wnioskowanych danych osobom fizycznym lub instytucjom znajduje obostrzenie w postaci sporządzenia przez administratora uzasadnienia. Udzielenie zgody przez Ministra Sprawiedliwości może być uzależnione od: uzupełnienia wniosku o informacje umożliwiające wyszukanie w zbiorze żądanych danych oraz o informacje o ich zakresie i przeznaczeniu; lub opinii podmiotu zatrudniającego wnioskującą osobę lub opinii jednostki nadrzędnej nad wnioskującym podmiotem - w zakresie uzasadnionej potrzeby posiadania przez wnioskodawcę danych, o których udostępnienie wystąpił ( $\$ 3$ ust. 2 powyżej przywołanego rozporządzenia). Jak wskazuje się w piśmiennictwie, "gromadzone $\mathrm{w}$ rejestrze informacje są szczególnie przydatne dla nauki socjologii, kryminologii czy prawa. Mogą one służyć m.in. do pomiaru przestępczości, badania jej struktury czy socjologicznego badania zachowań sprawców przestępstw"19.

\subsubsection{Udostępnienie danych osobowych zgromadzonych w Rejestrze Sprawców Przestępstw na Tle Seksualnym do celów badań naukowych}

Analogicznie jak w przypadku danych zgromadzonych w Krajowym Rejestrze Karnym, tak i w odniesieniu do danych osobowych przetwarzanych w Rejestrze Sprawców Przestępstw na Tle Seksualnym kwestie udostępnienia danych podmiotom uprawnionym do celów badań

${ }^{19}$ Zob. A. Nowakowska, M. Bojar, Krajowy Rejestr Karny jako baza danych i jego wykorzystanie, "Studies \& Proceedings of Polish Association for Knowledge Management" 2015, nr 74, s. 57. 
naukowych uregulowane zostały w ustawie oraz w sposób szczegółowy $\mathrm{w}$ akcie wykonawczym. Zgodnie $\mathrm{z}$ art. 17 ust. 1 Ustawy z dnia 13 maja 2016 r. o przeciwdziałaniu zagrożeniom przestępczością na tle seksualnym $^{20}$ "z wyłączeniem danych, o których mowa w art. 7 ust. 3 pkt 1 i 2, zgromadzone $w$ Rejestrze $\mathrm{z}$ dostępem ograniczonym dane mogą być przetwarzane i wykorzystywane do badań naukowych, a także, po pozbawieniu tych danych informacji identyfikujących osobę, do celów statystycznych". Ustawodawca ograniczył zakres danych osobowych, które mogą być udostępnione do celów badań naukowych, stąd też uwzględniając ogólną zasadę zgodności z prawem, rzetelności i przejrzystości statuowaną $w$ art. 5 ust. 1 lit. a ogólnego rozporządzenia, podmiot wnioskujący nie jest uprawniony do uzyskania danych (a administrator zobowiązany do udostępnienia danych) w zakresie numeru identyfikacyjnego Powszechnego Elektronicznego Systemu Ewidencji Ludności osoby ujętej w Rejestrze uzyskanego z rejestru PESEL, a także wizerunku twarzy osoby ujętej w Rejestrze uzyskanego z Rejestru Dowodów Osobistych. Do identyfikacji osoby ujętej w Rejestrze, której dane mogą być udostępnione do celów badań naukowych, w pełni mogą wystarczyć dane w postaci: nazwiska (w tym przybranego), imion, nazwiska rodowego, płci, daty i miejsca urodzenia, państwa urodzenia, imion rodziców, obywatelstwa lub obywatelstw, nazwiska rodowego matki oraz miejsca zamieszkania. Szczegółowe kwestie udostępniania danych osobowych z Rejestru Sprawców Przestępstw na Tle Seksualnym do celów badań naukowych reguluje Rozporządzenie Ministra Sprawiedliwości z dnia 13 marca 2017 r. w sprawie przetwarzania oraz przekazywania danych osobowych zgromadzonych w Rejestrze Sprawców Przestępstw na Tle Seksualnym do celów statystycznych oraz badań naukowych ${ }^{21}$. Zgodnie z $\S 3$ ust. 1 tego rozporządzenia udostępnienie danych osobowych do celów badań naukowych następuje na wniosek. Oznacza to, że organ nie może udostępnić danych w przypadku braku wniosku. Powołane rozporządzenie określa elementy wniosku o udostępnienie danych, do których zaliczyć należy: zwięzły opis celów badawczych wraz z uzasadnieniem, powody żądania danych wraz $z$ uzasadnieniem, zakres żądanych danych wraz z uzasadnieniem oraz informacje umożliwiające wyszukanie żądanych danych w zbiorze ( $\$ 3$ ust. 2 przywołanego powyżej aktu).

${ }^{20}$ Tekst jedn. Dz.U. 2018, poz. 405.

${ }^{21}$ Dz.U. 2017, poz. 656. 
Zarówno w przypadku udostępniania danych osobowych z Krajowego Rejestru Karnego, jak i Rejestru Sprawców Przestępstw na Tle Seksualnym, podmiot wnioskujący nie jest zobowiązany do legitymowania się zgodami osób, których dane dotycza, na udostępnienie danych. Wystarczające jest powołanie się na określone przepisy prawa. Warto jednak zwrócić uwagę, że źródłem udostępnianych danych są rejestry, a nie osoby, których dane dotycza, stąd też realizacja obowiązku informacyjnego powinna nastąić na podstawie art. 14, a nie 13 ogólnego rozporządzenia. Ze względu na to, że w tym przypadku przekazanie podmiotom danych zbioru informacji, o których mowa w art. 14 ust. 1 i 2 ogólnego rozporządzenia, nierzadko będzie niemożliwe, czy też będzie wymagało niewspółmiernie dużego wysiłku, zasadne będzie powołanie się na podstawę wyłączającą obowiązek informacyjny statuowaną $\mathrm{w}$ art. 14 ust. 5 lit. b ogólnego rozporządzenia. Zgodnie z powołanym przepisem administrator nie jest zobowiązany do spełnienia obowiązku informacyjnego, gdy - i w zakresie, w jakim - „udzielenie takich informacji okazuje się niemożliwe lub wymagałoby niewspółmiernie dużego wysiłku; w szczególności w przypadku przetwarzania do celów archiwalnych w interesie publicznym, do celów badań naukowych lub historycznych lub do celów statystycznych, z zastrzeżeniem warunków i zabezpieczeń, o których mowa w art. 89 ust. 1, lub o ile obowiązek, o którym mowa w ust. 1 niniejszego artykułu, może uniemożliwić lub poważnie utrudnić realizację celów takiego przetwarzania". Możliwość zastosowania powyższego wyłączenia obowiązku informacyjnego wynikającego z przetwarzania danych osobowych do celów badań naukowych dodatkowo potwierdza treść motywu 62 preambuły ogólnego rozporządzenia, a prawodawca wskazał, że "uwzględnić przy tym należy liczbę osób, których dane dotycza, okres przechowywania danych oraz wszelkie przyjęte odpowiednie zabezpieczenia".

Ogólne rozporządzenie nie wyłącza możliwości pozyskiwania danych z rejestrów jako alternatywnych źródeł danych, dla potwierdzenia czego należy powołać się na treść motywu 157 preambuły powyższego aktu normatywnego stanowiącego, że "łącząc ze sobą informacje z rejestrów, naukowcy mogą uzyskać nowa, wartościową wiedzę na przykład o częstych chorobach, takich jak choroba układu krążenia, rak czy depresja. Korzystając z rejestrów, można uściślić wyniki badań naukowych, gdyż będą się one opierać na większej próbie. W naukach społecznych badania oparte na rejestrach pozwalają naukowcom uzyskać kluczową wiedzę o długoterminowych współzależnościach wielu czynników społecznych, 
na przykład bezrobocia czy edukacji, z innymi czynnikami bytowymi. Wyniki badań uzyskane z rejestrów dostarczają solidnej, dobrej jakościowo wiedzy, która może posłużyć do opracowywania i realizowania polityki opartej na wiedzy, podnieść jakość życia wielu osób, a także zwiększyć skuteczność usług społecznych itp. Dla ułatwienia badań naukowych dopuszcza się przetwarzanie danych osobowych do celów badań naukowych z zastrzeżeniem odpowiednich warunków i zabezpieczeń przewidzianych w prawie Unii lub w prawie państwa członkowskiego".

\subsection{Podstawy dopuszczalności przetwarzania szczególnych kategorii danych osobowych}

Przepis art. 9 ust. 2 ogólnego rozporządzenia wskazuje podstawy dopuszczalności przetwarzania tzw. szczególnych kategorii danych osobowych. W sytuacji gdy administrator będzie przetwarzać do celów badań naukowych m.in. dane genetyczne bądź dane osobowe dotyczące zdrowia, konieczne będzie legitymowanie się jedną z przesłanek, o których mowa w art. 9 ust. 2 ogólnego rozporządzenia. Niemniej należy nadmienić, że prawodawca unijny w ogólnym rozporządzeniu w jednej z podstaw dopuszczalności przetwarzania danych odniósł się wprost do kwestii „badań naukowych", a mianowicie w art. 9 ust. 2 lit. j stanowiącym, iż uchylony zostaje generalny zakaz przetwarzania szczególnych kategorii danych osobowych, gdy "przetwarzanie jest niezbędne do celów archiwalnych w interesie publicznym, do celów badań naukowych lub historycznych lub do celów statystycznych zgodnie z art. 89 ust. 1, na podstawie prawa Unii lub prawa państwa członkowskiego, które są proporcjonalne do wyznaczonego celu, nie naruszają istoty prawa do ochrony danych i przewidują odpowiednie, konkretne środki ochrony praw podstawowych i interesów osoby, której dane dotyczą". Powołany przepis nie odnosi się wyłącznie do celu przetwarzania, lecz również do aspektu związanego z zapewnieniem bezpieczeństwa danych osobowych i przestrzeganiem zasady minimalizacji danych (co wynika z treści art. 89 ust. 1 ogólnego rozporządzenia). Omawiana przesłanka umożliwia przetwarzanie danych, o ile zezwalają na to przepisy prawa Unii Europejskiej lub przepisy prawa państwa członkowskiego. Przepis art. 9 ust. 2 lit. j ogólnego rozporządzenia wprowadza obostrzenie dotyczące przepisów prawa UE lub państwa członkowskiego, które powinny być proporcjonalne do wyznaczonego celu, a nadto nie powinny naruszać istoty prawa do ochrony danych. Ponadto przepisy 
unijne bądź krajowe powinny przewidywać odpowiednie, konkretne środki ochrony praw podstawowych i interesów osoby, której dane dotyczą. Nie każdy akt normatywny spełni wymagania w omawianym powyżej zakresie, stąd też w sytuacji, gdy przesłanka legalizująca przetwarzanie danych osobowych do celów badań naukowych nie znajdzie zastosowania, możliwe będzie powołanie się na inną podstawę wskazaną w art. 9 ust. 2 lit. a i ogólnego rozporządzenia. Przykładem alternatywnej podstawy może być wyraźna zgoda osoby, której dane dotycza, tj. art. 9 ust. 2 lit. a ogólnego rozporządzenia ${ }^{22}$.

\section{Realizacja praw osób, których dane dotyczą, w związku z przetwarzaniem danych osobowych do celów badań naukowych}

Ogólne rozporządzenie statuuje prawa osób, których dane dotyczą. Do tych praw zaliczyć należy: prawo dostępu przysługujące osobie, której dane dotyczą (art. 15); prawo do sprostowania danych (art. 16); prawo do usunięcia danych (tzw. „prawo do bycia zapomnianym”, art. 17); prawo do ograniczenia przetwarzania (art. 18); prawo do przenoszenia danych (art. 20), a także prawo do sprzeciwu (art. 21). Zgodnie z art. 89 ust. 2 ogólnego rozporządzenia "W przypadku przetwarzania danych osobowych do celów badań naukowych lub historycznych lub do celów statystycznych prawo Unii lub prawo państwa członkowskiego moga przewidzieć wyjątki od praw, o których mowa w art. 15, 16, 18 i 21, z zastrzeżeniem warunków i zabezpieczeń, o których mowa w ust. 1 niniejszego artykułu, jeżeli jest prawdopodobne, że prawa te uniemożliwią lub poważnie utrudnią realizację wspomnianych konkretnych celów, i jeżeli wyjątki takie są konieczne do realizacji tych celów". Korzystając z tzw. klauzuli option and choices, prawodawca wprowadził w ustawodawstwie krajowym możliwość ograniczenia korzystania z prawa dostępu do danych, prawa do sprostowania danych, prawa do ograniczenia przetwarzania oraz prawa do sprzeciwu. Jak stanowi art. $469 \mathrm{~b}$ ust. 1 Ustawy z dnia 20 lipca 2018 r. Prawo o szkolnictwie wyższym i nauce, "do przetwarzania danych osobowych przez podmioty, o których

${ }^{22}$ Jednocześnie należy podnieść, że zgoda osoby, której dane dotycza, może nie uchylić generalnego zakazu przetwarzania szczególnych kategorii danych osobowych, jeżeli przepisy prawa unijnego lub krajowego przewidują brak możliwości zniesienia tego zakazu w drodze złożenia oświadczenia podmiotu danych. 
mowa w art. 7 ust. 1 pkt 1 i 4-7, do celów badań naukowych i prac rozwojowych wyłącza się stosowanie przepisów art. 15, art. 16, art. 18 i art. 21 rozporządzenia 2016/679, jeżeli zachodzi prawdopodobieństwo, że prawa określone w tych przepisach uniemożliwią lub poważnie utrudnią realizację celów badań naukowych i prac rozwojowych, i jeżeli wyłączenia te są konieczne do realizacji tych celów". Oznacza to, że przetwarzanie m.in. przez uczelnie danych osobowych do celów badań naukowych może wiązać się z ograniczeniem realizacji niektórych praw podmiotów danych. Ustawodawstwo krajowe nie wyłącza jednak możliwości korzystania z prawa do usunięcia danych i prawa do przenoszenia danych osobowych. Warto wszakże nadmienić, że wyłączenie prawa do usunięcia danych osobowych (prawa do bycia zapomnianym) w procesach przetwarzania danych do celów badań naukowych prowadziłoby do pozbawienia jednostki jednego z praw, którego realizacja ewidentnie stanowi przejaw autonomii informacyjnej podmiotu danych. Administrator, przetwarzając dane osobowe do celów badań naukowych, powinien zatem wyważyć, czy realizacja określonych praw osób fizycznych uniemożliwi, bądź też poważnie utrudni osiągnięcie celu przetwarzania. Pozostawienie przez prawodawcę $w$ tym zakresie luzu decyzyjnego wiąże się z wystąpieniem ryzyka dokonania przez administratora nieprawidłowej oceny co do możliwości realizacji praw podmiotów danych. Warto jednocześnie zwrócić uwagę, że naruszenia przepisów ogólnego rozporządzenia dotyczących praw osób, których dane dotycza, o których mowa w art. 12-22, podlegają administracyjnej karze pieniężnej w wysokości do $20 \mathrm{mln}$ euro, a w przypadku przedsiębiorstwa - w wysokości do $4 \%$ całkowitego rocznego światowego obrotu z poprzedniego roku obrotowego, przy czym zastosowanie ma kwota wyższa - art. 83 ust. 5 lit. b ogólnego rozporządzenia. Bezzasadne powoływanie się na niemożność lub utrudnienie w osiągnięciu celu przetwarzania danych do badań naukowych może prowadzić do poniesienia odpowiedzialności przez administratora.

\section{Przetwarzanie szczególnych kategorii danych osobowych do celów badań naukowych}

Przepis art. 469b ust. 2 ustawy Prawo o szkolnictwie wyższym i nauce stanowi, że „w zakresie niezbędnym do prowadzenia badań naukowych i prac rozwojowych dopuszcza się przetwarzanie danych 
osobowych ujawniających pochodzenie rasowe lub etniczne, poglądy polityczne, przekonania religijne lub światopoglądowe, przynależność do związków zawodowych oraz przetwarzanie danych genetycznych, danych biometrycznych $\mathrm{w}$ celu jednoznacznego zidentyfikowania osoby fizycznej lub danych dotyczących zdrowia, seksualności lub orientacji seksualnej tej osoby, pod warunkiem że publikowanie wyników tych badań i prac następuje w sposób uniemożliwiający identyfikację osoby fizycznej, której dane zostały przetworzone". Administrator jest uprawniony do przetwarzania danych osobowych szczególnych kategorii wówczas, gdy jest to niezbędne do prowadzenia badań naukowych. Niemniej w ustawodawstwie krajowym wprowadzono obostrzenie dotyczące przetwarzania szczególnych kategorii danych osobowych na potrzeby badań naukowych, które polega na zakazie publikacji $\mathrm{w}$ wynikach badań naukowych tego rodzaju informacji umożliwiających identyfikację osoby. Publikacja wyników badań naukowych - w szczególności związana z upowszechnianiem dostępu do wyników badań naukowych w ramach otwartego dostępu do publikacji i wyników badań naukowych - bez dokonania pseudonimizacji lub anonimizacji danych osobowych przetwarzanych na potrzeby tychże badań może prowadzić do naruszenia ochrony danych osobowych w myśl art. 4 pkt 12 ogólnego rozporządzenia. Zgodnie z definicją legalną pod pojęciem naruszenia ochrony danych osobowych rozumieć należy również nieuprawnione ujawnienie danych osobowych. W sytuacji gdy jest prawdopodobne, że naruszenie ochrony danych osobowych skutkować będzie wystąpieniem ryzyka naruszenia praw lub wolności osób fizycznych, administrator jest zobowiązany do zgłoszenia naruszenia organowi nadzorczemu (tj. Prezesowi Urzędu Ochrony Danych Osobowych). W przypadku szczególnych kategorii danych osobowych wystąpienie ryzyka naruszenia praw lub wolności osoby fizycznej jest większe, gdyż faktycznie może prowadzić m.in. do uszczerbku fizycznego, czy też szkód majątkowych lub niemajątkowych.

Konkludując, administrator przetwarzający dane osobowe do celów badań naukowych będzie uprawniony do przetwarzania szczególnych kategorii danych, o ile te dane będą przetwarzane w zakresie niezbędnym do osiągnięcia celu przetwarzania, a także po dokonaniu czynności mających na celu uniemożliwienie identyfikacji podmiotów danych w przypadku publikowania wyników badań. Powyższe warunki powinny być spełnione łącznie. 


\section{Wdrożenie odpowiednich środków technicznych i organizacyjnych przy przetwarzaniu danych osobowych do celów badań naukowych}

Ogólne rozporządzenie nakłada na administratorów obowiązek wdrożenia odpowiednich środków technicznych i organizacyjnych, przy czym ten akt normatywny nie zobowiązuje do stosowania określonych zabezpieczeń. Prawodawca dobór środków technicznych i organizacyjnych pozostawił do decyzji administratorów, którzy powinni uwzględniać charakter, zakres, kontekst i cele przetwarzania oraz ryzyko naruszenia praw lub wolności osób fizycznych o różnym prawdopodobieństwie i wadze (vide art. 24 ust. 1 ogólnego rozporządzenia). Warto jednak nadmienić, że ogólne rozporządzenie wskazuje przykładowe środki techniczne i organizacyjne, których wdrożenie ma zapewnić stopień bezpieczeństwa odpowiadający ryzyku naruszenia praw lub wolności podmiotów danych. Do takich środków zaliczyć należy: pseudonimizację i szyfrowanie danych osobowych; zdolność do ciągłego zapewnienia poufności, integralności, dostępności i odporności systemów i usług przetwarzania; zdolność do szybkiego przywrócenia dostępności danych osobowych i dostępu do nich w razie incydentu fizycznego lub technicznego; a także regularne testowanie, mierzenie i ocenianie skuteczności środków technicznych i organizacyjnych mających zapewnić bezpieczeństwo przetwarzania (art. 32 ust. 1 ogólnego rozporządzenia). Ponadto jeżeli jest to proporcjonalne $\mathrm{w}$ stosunku do czynności przetwarzania, administrator powinien wdrożyć odpowiednie polityki ochrony danych, o czym stanowi art. 24 ust. 2 ogólnego rozporządzenia. Administrator powinien rozważyć nadanie stosownych upoważnień do przetwarzania danych osobowych osobom, które będą przetwarzać dane do celów badań naukowych ( $\mathrm{tj}$. będą działać z upoważnienia administratora i mieć dostęp do danych osobowych, przetwarzając je wyłącznie na polecenie tego podmiotu), chyba że wymaga tego prawo Unii lub prawo państwa członkowskiego, o czym stanowi wprost art. 29 ogólnego rozporządzenia.

Ustawodawstwo krajowe również odnosi się do zagadnienia bezpieczeństwa przetwarzania, zgodnie bowiem z art. $469 \mathrm{~b}$ ust. 3 ustawy Prawo o szkolnictwie wyższym i nauce "przy przetwarzaniu danych osobowych, o których mowa w ust. 1 i 2, administrator danych wdraża odpowiednie zabezpieczenia techniczne i organizacyjne praw 
i wolności osób fizycznych, których dane osobowe są przetwarzane, zgodnie z rozporząadzeniem 2016/679, w szczególności przez pseudonimizację albo szyfrowanie danych, nadawanie uprawnień do ich przetwarzania minimalnej liczbie osób niezbędnych do prowadzenia badań naukowych i prac rozwojowych, kontrolę dostępu do pomieszczeń, w których przechowywane są dokumenty zawierające dane osobowe, oraz opracowanie procedury określającej sposób zabezpieczenia danych". Warto zwrócić uwagę na konstrukcję prawną przepisów art. 32 ust. 1 i art. $469 \mathrm{~b}$ ust. 3 ogólnego rozporządzenia. W ogólnym rozporządzeniu prawodawca unijny posługuje się zwrotem „w stosownym przypadku", odnosząc się do konkretnych środków technicznych i organizacyjnych, które może wdrożyć administrator, natomiast prawodawca krajowy zobowiązuje wprost do wdrożenia szczególnych środków zabezpieczeń, nie pozostawiając administratorowi swobody w doborze tychże środków. Można podać w wątpliwość, czy ustawodawca był uprawniony do ukształtowania obowiązku wdrożenia odpowiednich środków w taki sposób, gdyż stanowi to ingerencję w swobodę kształtowania modelu stosowanych zabezpieczeń, tak jak miało to miejsce na gruncie poprzednio obowiązującego Rozporządzenia Ministra Spraw Wewnętrznych i Administracji z dnia 29 kwietnia 2004 r. w sprawie dokumentacji przetwarzania danych osobowych oraz warunków technicznych i organizacyjnych, jakim powinny odpowiadać urządzenia i systemy informatyczne służące do przetwarzania danych osobowych $^{23}$. Należy nadmienić, że wdrożenie środków technicznych i organizacyjnych, o których mowa w art. 469b ust. 2 ustawy Prawo o szkolnictwie wyższym i nauce, może nie prowadzić do zapewnienia odpowiedniego poziomu bezpieczeństwa ${ }^{24}$. Ponadto ingerencję przez ustawodawcę w dobór środków technicznych i organizacyjnych należy ocenić negatywnie, gdyż jest to rola administratora, wobec którego organ nadzorczy może zastosować administracyjną karę pieniężną. Zgodnie z art. 83 ust. 2 zd. 2 lit. d ogólnego rozporządzenia, „decydując, czy nałożyć administracyjną karę pieniężna, oraz ustalając jej wysokość, zwraca się w każdym indywidualnym przypadku należytą uwagę na stopień odpowiedzialności administratora lub podmiotu przetwarzającego z uwzględnieniem środków technicznych i organizacyjnych

${ }^{23}$ Dz.U. Nr 100, poz. 1024.

${ }^{24}$ Tak też A. Mrozowska, Zasady przetwarzania danych osobowych do celów badań naukowych i prac rozwojowych, w: Prawo o szkolnictwie wyższym i nauce. Komentarz, pod red. J. Woźnickiego, Warszawa 2019. 
wdrożonych przez nich na mocy art. 25 i 32". Administrator powinien raczej rozważyć wdrożenie zalecanych środków bezpieczeństwa, które określają normy Międzynarodowej Organizacji Normalizacyjnej $(\mathrm{ISO})^{25}$.

\section{Anonimizacja danych osobowych przetwarzanych do celów badań naukowych}

Jak stanowi art. $469 \mathrm{~b}$ ust. 4 ustawy Prawo o szkolnictwie wyższym i nauce, "dane osobowe, o których mowa w ust. 1 i 2, poddaje się anonimizacji niezwłocznie po osiągnięciu celu badań naukowych lub prac rozwojowych. Do tego czasu dane, które można wykorzystać do identyfikacji danej osoby fizycznej, zapisuje się osobno. Można je łączyć z informacjami szczegółowymi dotyczącymi danej osoby fizycznej wyłącznie, jeżeli wymaga tego cel badań naukowych lub prac rozwojowych". Ogólne rozporządzenie nie wprowadziło definicji legalnej pojęcia ",anonimizacji”, tak jak w przypadku "pseudonimizacji” (vide art. 4 pkt 5), niemniej określenie „zanonimizowanych" pojawia się w motywie 26 preambuły, zgodnie z treścią którego „zasady ochrony danych nie powinny [...] mieć zastosowania do informacji anonimowych, czyli informacji, które nie wiążą się ze zidentyfikowaną lub możliwą do zidentyfikowania osobar fizyczna, ani do danych osobowych zanonimizowanych w taki sposób, że osób, których dane dotycza, w ogóle nie można zidentyfikować lub już nie można zidentyfikować". Proces anonimizacji ma na celu uniemożliwienie dalszej identyfikacji osoby fizycznej, a tym samym definitywne zakończenie procesu przetwarzania danych osobowych. Warto jednocześnie podkreślić, że anonimizacja nie dotyczy wyłącznie danych osobowych przetwarzanych w dokumentacji papierowej, lecz również przetwarzanych w wersji elektronicznej. W ustawodawstwie krajowym administrator przetwarzający dane osobowe do celów badań naukowych nie jest zobowiązany do usunięcia wszelkich danych po osiągnięciu celu przetwarzania, lecz do dokonania anonimizacji polegającej na uniemożliwieniu przypisania informacji identyfikujących osoby fizyczne tym danym, które wykorzystano do badań. W sytuacji gdy administrator dokonał anonimizacji, dalsze przetwarzanie nie będzie się

${ }^{25}$ Szerzej zob. M. Byczkowski, Znaczenie norm ISO we wdrażaniu bezpieczeństwa technicznego i organizacyjnego wymaganego w RODO, „Monitor Prawniczy” 2017, nr 20, dodatek. 
wiązało z przetwarzaniem danych osobowych, co oznacza wyłączenie stosowania ogólnego rozporządzenia. Jak wynika z treści powołanego już motywu 26 preambuły ogólnego rozporządzenia, „niniejsze rozporządzenie nie dotyczy więc przetwarzania takich anonimowych informacji, w tym przetwarzania do celów statystycznych lub naukowych". Taka sytuacja może być korzystna dla podmiotów, które przetwarzają dane uniemożliwiające identyfikację osób fizycznych do celów badań naukowych, a którym to dane zanonimizowane zostały udostępnione. Jako przykład należy wskazać udostępnienie danych zawartych w rejestrach medycznych (stanowiących uporządkowane zbiory danych osobowych, w tym jednostkowych danych medycznych) do celów prowadzenia badań naukowych i do celów statystycznych w formie uniemożliwiającej ich powiązanie z konkretną osobą fizyczną na podstawie art. 19 ust. 7 Ustawy z dnia 28 kwietnia 2011 r. o systemie informacji w ochronie zdrowia ${ }^{26}$. Ponadto jako przykład udostępnienia zanonimizowanych danych należy wskazać przypadek, gdy dane szczególnych kategorii, takie jak dane dotyczące zdrowia zawarte w dokumentacji medycznej, mogą być udostępnione szkole wyższej lub instytutowi badawczemu do wykorzystania w celach naukowych, przy czym dane te powinny być pozbawione cech identyfikacyjnych osoby, której dokumentacja dotyczy ${ }^{27}$.

\section{Przetwarzanie danych osobowych do celów badań naukowych przez biobanki}

Szczególnie interesującym zagadnieniem, które odnosi się do przetwarzania danych osobowych do celów badań naukowych, jest problematyka przetwarzania danych przez biobanki. Pojęcie "biobank" zostało zdefiniowane m.in. przez Organizację Współpracy Gospodarczej i Rozwoju w rekomendacjach dotyczących biobankowania materiału ludzkiego i tworzenia baz danych genetycznych dla celów badań naukowych $^{28}$. Jak wskazuje się $\mathrm{w}$ treści powyższego dokumentu, biobanki to „zorganizowane zasoby, które zawierają: 1) materiały biologiczne

${ }^{26}$ Tekst jedn. Dz.U. 2019, poz. 408.

${ }^{27}$ Przepis art. 26 ust. 4 Ustawy z dnia 6 XI 2008 r. o prawach pacjenta i Rzeczniku Praw Pacjenta (tekst jedn. Dz.U. 2019, poz. 1127).

${ }^{28}$ http://www.oecd.org/sti/emerging-tech/44054609.pdf (dostęp: 14 XII 2019). 
pochodzenia ludzkiego i (lub) wygenerowane z nich dane; 2) powiązane z nimi informacje dodatkowe, podkreślając jednocześnie, że mogą one być wykorzystane do prowadzenia badań naukowych nad genetyką człowieka"29. Zgodnie natomiast z definicją sformułowaną przez Europejską Grupę ds. Etyki i Badań Nowych Technologii, powołaną przez Komisję Europejska, pod pojęciem biobanku należy rozumieć "różnego typu zbiory próbek biologicznych wraz z powiązanymi z nimi bazami danych, które mają pewien poziom dostępności, osiągalności i wymiany dla celów naukowych" ${ }^{\prime 30}$. W świetle powyższych definicji nie sposób twierdzić, że biobanki nie przetwarzają danych osobowych ${ }^{31}$. Prawodawca unijny nie wyłączył w tym przypadku stosowania ogólnego rozporządzenia, dlatego ten akt normatywny znajdzie zastosowanie do procesów przetwarzania danych osobowych w celu biobankowania materiału ludzkiego i tworzenia baz danych genetycznych do celów badań naukowych. Zgodnie z art. 4 pkt 13 ogólnego rozporządzenia pod pojęciem danych genetycznych należy rozumieć "dane osobowe dotyczące odziedziczonych lub nabytych cech genetycznych osoby fizycznej, które ujawniają niepowtarzalne informacje o fizjologii lub zdrowiu tej osoby i które wynikają w szczególności z analizy próbki biologicznej pochodzącej od tej osoby fizycznej". Dane genetyczne należy zaliczyć do szczególnej kategorii danych osobowych, stąd też biobanki, przetwarzając te dane do celów badań naukowych, powinny legitymować się jedną z podstaw dopuszczalności przetwarzania,

${ }^{29}$ Tak: J. Pawlikowski, Ochrona prywatności dawców w kontekście biobankowania ludzkiego materiału biologicznego dla celów badań naukowych, w: Temida w dobie rewolucji biotechnologicznej. Wybrane problemy bioprawa, pod red. O. Nawrota, A. Wnukiewicz-Kozłowskiej, Gdańsk 2015, s. 163-186. W treści rekomendacji OECD wskazano: „human biobanks and genetic research databases $($ „HBGRD”), which are structured resources that can be used for the purpose of genetic research and which include: (a) human biological materials and/or information generated from the analysis of the same; and (b) extensive associated information". W piśmiennictwie można się spotkać również z innymi definicjami biobanku, np.: „biobank można zdefiniować jako zbiór materiału biologicznego pochodzenia ludzkiego (tkanek, komórek, w tym komórek rozrodczych wykorzystywanych w metodach sztucznej prokreacji, krwi czy DNA) (M. Grzymowska, Standardy bioetyczne w prawie europejskim, Warszawa 2009, s. 139).

${ }^{30}$ Zob. D. Krekora-Zając, O konieczności regulacji prawnej biobanków, „Państwo i Prawo” 2012 , z. 7, s. 64-77.

${ }^{31}$ Szerzej zob.: D. Krekora-Zając, Prawo dawców do autonomii i prywatności jako podstawa funkcjonowania biobanków w czasach Big Data, "Studia Iuridica” 2018, t. 73, s. 57-71; B. Marciniak, P. Topolski, D. Strapagiel, Anonimizacja w dobie wielkich danych - sytuacja biobanków w kontekście RODO, „Studia Iuridica” 2018, t. 73, s. 73-85; K. Łakomiec, Biobanki w dobie Big Data z perspektywy prawa konstytucyjnego, "Studia Iuridica” 2018, t. 73, s. 105-118. 
o których mowa w art. 9 ust. 2 ogólnego rozporządzenia ${ }^{32}$. Warto jednocześnie nadmienić, że w świetle ogólnego rozporządzenia „państwa członkowskie moga zachować lub wprowadzić dalsze warunki, w tym ograniczenia w odniesieniu do przetwarzania danych genetycznych, danych biometrycznych lub danych dotyczących zdrowia" (art. 9 ust. 4). Tym samym dopuszczalne jest uregulowanie w ustawodawstwie krajowym warunków, a nawet ograniczeń odnoszących się do przetwarzania przez biobanki m.in. danych genetycznych lub dotyczących zdrowia. Nie ma wątpliwości co do zakresu zastosowania ogólnego rozporządzenia do procesów przetwarzania danych osobowych w celach badań naukowych przez biobanki, gdyż ten akt normatywny obowiązuje bez wyłączeń. Taki pogląd ukształtowany został już na gruncie ustawy o ochronie danych osobowych z 1997 r., a mianowicie: „biorąc pod uwagę powyższe, zasadne jest przyjęcie, że do czynności wykonywanych $\mathrm{w}$ biobanku będą miały zastosowanie zarówno normy odnoszące się do czynności wykonywanych na materiale biologicznym pochodzącym od człowieka, jak i normy regulujące procesy przetwarzania informacji o jednostce ${ }^{\prime 33}$. Niezależnie zatem od faktu, czy biobank funkcjonuje jako jednostka posiadająca osobowość prawna, czy też nie, może być uznany za administratora. W następstwie tego biobank będzie zobowiązany do przestrzegania przepisów ogólnego rozporządzenia, w tym m.in. respektowania zasad ogólnych dotyczących przetwarzania danych osobowych, legitymowania się właściwą podstawą dopuszczalności przetwarzania danych, realizowania obowiązku informacyjnego oraz praw podmiotów danych, stosowania odpowiednich środków technicznych i organizacyjnych czy prowadzenia rejestru czynności przetwarzania danych.

\section{Podsumowanie}

Niniejszy artykuł odnosi się do problematyki przetwarzania danych osobowych do celów badań naukowych. Tematyka ta była stosunkowo rzadko poruszana w piśmiennictwie, niemniej w ocenie autorki wymaga przeprowadzenia dogłębniejszej analizy, m.in. ze względu na niejednokrotne odniesienia do kwestii badań naukowych przez prawodawcę

${ }^{32}$ Szerzej na temat ochrony danych genetycznych zob. A. Mednis, Ochrona danych genetycznych jako danych osobowych, "Studia Iuridica” 2018, t. 73, s. 87-103.

${ }^{33}$ Zob. K. Łakomiec, Wybrane konstytucyjne aspekty funkcjonowania biobanków populacyjnych, „Państwo i Prawo” 2014, z. 12, s. 54-64. 
unijnego w ogólnym rozporządzeniu, czy też uregulowanie kwestii stosowania powyższego aktu normatywnego w kontekście badań naukowych prowadzonych przez podmioty wskazane w ustawie Prawo o szkolnictwie wyższym i nauce (m.in. uczelnie, instytuty naukowe Polskiej Akademii Nauk, instytuty badawcze, międzynarodowe instytuty naukowe utworzone na podstawie odrębnych ustaw działające na terytorium Rzeczypospolitej Polskiej, Centrum Łukasiewicz, instytuty działające w ramach Sieci Badawczej Łukasiewicz czy Polska Akademia Umiejętności). O istocie badań naukowych prowadzonych m.in. przez uczelnie świadczy choćby fakt, że jest to jedno z ich podstawowych (kluczowych) zadań, do którego odniesienia znaleźć można już w samej preambule do ustawy Prawo o szkolnictwie wyższym i nauce. Ponadto ustawa zasadnicza zapewnia każdemu wolność prowadzenia badań naukowych i ogłaszania ich wyników (vide art. 73 Konstytucji Rzeczypospolitej Polskiej z dnia 2 kwietnia $1997 \mathrm{r}^{34}$ ). Nierzadko na potrzeby prowadzonych badań naukowych konieczne będzie przetwarzanie danych osobowych, co wiąże się z obowiązkiem respektowania praw osób, których dane dotyczą (tzw. podmiotów danych). Podmioty prowadzące badania naukowe, które do tego celu przetwarzają dane osobowe, są zobowiązane do stosowania ogólnego rozporządzenia regulującego m.in. obowiązki ciążące na administratorach.

\section{THE PROCESSING OF PERSONAL DATA FOR THE PURPOSES OF SCIENTIFIC RESEARCH. LEGAL ASPECTS}

\section{Sum mary}

This article refers to the issue of personal data processing conducted in connection with scientific research and in accordance with the provisions of Regulation (EU) 2016/679 of the European Parliament and of the Council of 27 April 2016 on the protection of natural persons with regard to the processing of personal data and on the free movement of such data, and repealing Directive 95/46/EC (General Data Protection Regulation). It is not uncommon for the purposes of scientific research to process personal data, which is connected with the obligation to respect the rights of the data of the subjects involved. Entities conducting scientific research that process personal data for this purpose are required to apply the general regulation governing, among others, the obligations imposed on the controllers. The issue of personal data processing for scientific research purposes has also been regulated in national legislation in connection with the need to apply the General

\footnotetext{
${ }^{34}$ Dz.U. Nr 78, poz. 483 ze zm.
} 
Data Protection Regulation. The article discusses the basics of the admissibility of data processing for the needs of scientific research; providing personal data regarding criminal convictions and offences extracted from public registers at the request of the entity conducting scientific research; exercising the rights of the data of the subjects concerned; as well as the implementation of appropriate technical and organizational measures to ensure the security of data processing. In addition, the article discusses the issue of anonymization of personal data carried out after achieving the purpose of personal data processing, as well as the processing of special categories of personal data. The topics discussed in the article were not discussed in detail, as this would require further elaboration in a publication with a much wider volume range.

Keywords: scientific research - GDPR - controller - personal data - processing 